Arboriculture \& Urban Forestry 2014. 40(4): 237-243

\title{
Comparative Assessment of Phosphite Formulations for Apple Scab (Venturia inaequalis) Control
}

\author{
Luke E. Hailey and Glynn C. Percival
}

\begin{abstract}
Potassium phosphite is a widely used plant protection agent. However, a suite of phosphite formulations with alternative cation attachments (calcium, copper, silicon, zinc) are commercially available. The plant protective properties of these formulations have received little attention. This study evaluated five phosphite formulations for plant protection purposes against the foliar pathogen apple scab (Venturia inaequalis) under field conditions. In addition, a comparative analysis against the synthetic fungicide penconazole, which is widely used for apple scab control, was conducted. Greatest reductions in leaf and fruit scab severity were achieved by sprays of the synthetic fungicide penconazole. However, all phosphite formulations evaluated significantly reduced leaf and fruit scab severity at the cessation of the growing season. Within the phosphites tested, the greatest reductions in leaf and fruit scab severity were achieved in the order: copper phosphite $>$ silicon phosphite $>$ zinc phosphite $>$ calcium phosphite $>$ potassium phosphite $>$ control. The advantages and disadvantages of these phosphite formulations for scab control are discussed.

Key Words. Apple Management; Apple Scab; Fungicide; Integrated Disease Management; Pathogen Control; Plant Health Care; Systemic Induced Resistance; Venturia inaequalis.
\end{abstract}

Apple scab (Venturia inaequalis) is an ascomycete fungus and economically important pathogen of ornamental apple varieties and cultivars as well as apples cultivated for human consumption (Percival et al. 2009). The fungus causes cosmetic damage to fruit, which in turn reduces quality and yield. As producers, suppliers, and vendors of apples adopt a zero-tolerance policy towards scab on fruit (Butt et al. 1990), UK growers generally apply 12-18 synthetic fungicide sprays throughout the growing season (Butt et al. 1990; Swait and Butt 1990) to reduce scab levels to commercially accepted standards. Increased awareness of environmental and health issues, coupled with the emergence of fungicide-tolerant strains of apple scab, has placed greater emphasis on the development of alternative scab control strategies (Gozzo 2003; Fobert and Després 2005; Ilhan et al. 2006).

Inorganic phosphite salts are a family of potential plant protection agents (Lobato et al. 2008; Miller et al. 2006; Percival et al. 2009). Phosphites, when applied to plants as a foliar spray or soil drench, exhibit two modes of action: acting directly on the pathogen and acting indirectly by stimulating plant host defense responses, a concept known as systemic induced resistance (SIR). SIR responses include the accumulation of phytoalexins, hypersensitive cell death, cell wall lignification, and formation of lytic enzymes that in turn inhibit pathogen growth (Guest and Grant 1991; Garbelotto et al. 2007). Research in Australia and the United States has found potassium phosphite salts to be effective in the control of Phytophthora root rot and canker pathogens (Jackson et al. 2000; Miller et al. 2006). In addition, potassium phosphite has been shown to suppress Venturia inaequalis (apple scab) and Erwinia amylovora (apple fire blight) (Percival et al. 2009).

Most research to date has focused on the plant protection properties of potassium phosphite, as this represents the primary formulation sold for commercial plant protection purposes. However a suite of phosphite formulations with alternative cation attachments (calcium, copper, silicon, zinc) are commercially available. These alterna- 
tive phosphite formulations may potentially have a higher efficacy against fungal pathogens, such as apple scab. Comparison of their efficacy has, however, received little attention (Lobato et al. 2008). Certain metal cations, such as copper and zinc, are well recognized for their anti-microbial effects when applied at low concentrations (Nägeli 1893). Indeed, foliar sprays of copper are one of the oldest forms of pathogen control, acting in a protective fashion (Johnson 1935). Cations such as calcium and silicon are linked to improved disease resistance by indirect manipulation of host plant physiology. Applications of calcium, for example, increase cell wall strength through esterification of cellular membranes, thereby enhancing resistance to fungal and bacterial enzymatic degradation (Marschner 2012). Silicon is a major mineral constituent of plants that enhances growth and can strengthen cell wall integrity as well as mitigate abiotic stresses, such as nutrient imbalance, salinity, drought, and UV damage (Epstein 1999; Epstein 2001; Liang et al. 2005; Currie and Perry 2007; Marschner 2012). Silicon also has SIR activity (Fauteux et al. 2006).

Aims of this study were to evaluate five phosphite formulations for plant protection purposes against the biotrophic foliar pathogen apple scab under field conditions.

\section{MATERIALS AND METHODS}

\section{Trial Site}

The apple trial site consisted of a 0.75 ha block of apple (Malus cv. Golden Delicious) interspersed with individual trees of Malus cv. Red Delicious and cv. Gala as pollinators. Golden Delicious was chosen for the experiment due to its susceptibility to apple scab infection. Planting distances were based on $2 \mathrm{~m} \times 2 \mathrm{~m}$ spacing. The trees were planted in 2003 and trained under the central-leader system to an average height of $2.5 \mathrm{~m} \pm 0.25 \mathrm{~m}$ with mean trunk diameters of $12 \mathrm{~cm} \pm 1.4 \mathrm{~cm}$ at $45 \mathrm{~cm}$ above the soil level. The trial sites were located at the University of Reading Shinfield Experimental Site, University of Reading, Berkshire (N51 ${ }^{\circ} 43$, $\left.\mathrm{W}-1^{\circ} 08\right)$. The soil was a sandy loam containing $4 \%-6 \%$ organic matter, $\mathrm{pH}$ of 6.2 , and available $\mathrm{P}$, $\mathrm{K}, \mathrm{Mg}, \mathrm{Na}$, and $\mathrm{Ca}$ of 52.0, 659.1, 175.2, 49.4, and $2188 \mathrm{mg} \mathrm{l}^{-1}$, respectively. Weeds were controlled chemically using glyphosate (Roundup; GreenTech, Sweethills Park, Nun Monkton, York, UK) throughout experiments. No watering or fertilization was applied during the trial. Historically, the apples suffered from apple scab infection on an annual basis (Percival et al. 2009). The experiment was conducted in 2012. The treatments, five phosphite formulations, one fungicide, were applied in eight randomized complete blocks plus a water control with a single tree as the experimental unit.

\section{Fungicide and Phosphite Treatments}

Trees were sprayed until runoff four times throughout the growing season in accordance with specific phenological stages; bud break (March 23), green cluster (April 5), 90\% petal drop (May 23), and early fruitlet formation (June 9) (Bevan and Knight 2001), with a range of phosphites and a water control (Table 1). For all phosphite formulations, a dilution of $10 \mathrm{ml}$ per liter of water was used. In addition, a comparative evaluation of a conventional synthetic fungicide penconazole (trade name Topas), used within the UK for apple scab control, applied at $1.5 \mathrm{ml}$ per liter of water was undertaken. All phosphite products and penconazole fungicide were supplied by Orion Future Technology Ltd. (Henwood House, Henwood, Ashford, Kent). Eight trees per treatment were used.

Table 1. Phosphite formulations and synthetic fungicide applied to apple (Malus cv. Golden Delicious) against apple scab, Venturia inaequalis.

\begin{tabular}{ll}
\hline Product & Formula \\
\hline Penconazole & $\mathrm{C}_{13} \mathrm{H}_{15} \mathrm{C}_{12} \mathrm{~N}_{3}$ \\
Potassium phosphite & $\mathrm{H}_{2} \mathrm{KO}_{3} \mathrm{P}$ \\
Zinc phosphite & $\mathrm{O}_{6} \mathrm{P}_{2} \mathrm{Zn}_{3}$ \\
Silicon phosphite & $\mathrm{Si}_{3}\left(\mathrm{PO}_{3}\right)_{2}$ \\
Copper phosphite & $\mathrm{Cu}_{3} \mathrm{PO}_{3}$ \\
Calcium phosphite & $\mathrm{Ca}_{3} \mathrm{O}_{6} \mathrm{P}_{2}$ \\
\hline
\end{tabular}

\section{Scab Severity and Yield Assessment}

Scab severity of leaves and fruit was assessed visually. Leaf scab severity of each tree was rated using a visual indexing technique and ratings on a $0-5$ scale: $0=$ no scab observed; $1=$ less than $5 \%$ of leaves affected and no aesthetic impact; 2 $=5 \%-20 \%$ of leaves affected with some yellowing but little or no defoliation; $3=21 \%-50 \%$ of leaves affected, significant defoliation and/or leaf yellowing; $4=51 \%-80 \%$ of leaves affected, severe 
foliar discoloration; $5=81 \%-100 \%$ of leaves affected with $90 \%-100 \%$ defoliation (Butt et al. 1990)

Scab severity on fruit was rated on a $0-5$ scale: $0=$ no visible lesions; $1=<10 \%$ fruit surface infected; $2=10 \%-25 \%$ fruit surface infected; $3=25 \%-50 \%$ fruit surface infected; $4=>50 \%$ fruit surface infected (Swait and Butt 1990).

Yield per tree was determined by weighing all fruit on each tree at harvest and dividing by the number of trees per treatment.

\section{Leaf Chlorophyll Content}

Chlorophyll content (SPAD) readings were taken as an indication of plant vitality. To keep the physiological age of the leaves comparable throughout the experiment, measurements were made only on fully expanded, mature leaves. In all cases, SPAD measurements were taken from six leaves per tree (two from the top of the crown, two in the center, and two at the base). A Minolta chlorophyll meter SPAD-502 was used. Chlorophyll was measured at the midpoint of the leaf next to the main leaf vein. Calibration was obtained by measurement of absorbance at 663 and $645 \mathrm{~nm}$ in a spectrophotometer (PU8800 Pye Unicam) after extraction with $80 \% \mathrm{v} / \mathrm{v}$ aqueous acetone (regr. eq. $=5.78+0.0483 \mathrm{x} ; \mathrm{r}^{2}$ adj $=0.93$, $P \leq 0.001$ ) (Lichtenthaler and Wellburn 1983).

\section{Statistical Analysis}

Mean scab severity values treatments were transformed using the Arcsin $\left(\right.$ sine $\left.^{-1}\right)$ transformation. All data were analyzed using ANOVA and the differences from controls were determined using Least Significant Differences $(P=$ 0.05) using the GenStat for Windows program. Back transformed scab severity values are presented here to ease interpretation of the data.

\section{RESULTS}

Greatest increases in fruit yield and leaf chlorophyll content (SPAD values) were achieved after spraying the synthetic fungicide penconazole where values were $53.1 \%$ and $88.8 \%$ higher than controls, respectively (Table 2). Within the phosphite formulations evaluated the highest fruit yield per tree $(\mathrm{kg})$ was achieved in the order: copper phosphite $>$ silicon phosphite $>$ potassium phosphite $>$ zinc phosphite $>$ calcium phosphite $>$ control while the highest leaf chlorophyll content was achieved in the order: copper phosphite $>$ zinc phosphite $>$ silicon phosphite $>$ potassium phosphite $>$ calcium phosphite $>$ control. All phosphite formulations evaluated significantly $(P<0.05)$ increased leaf chlorophyll content and fruit yield at the cessation of the growing season with one exception, calcium phosphite, where fruit yields were higher than control trees but not significantly so (Table 2).

Greatest reductions in leaf and fruit scab severity and were achieved after spraying the synthetic fungicide penconazole, where values were $88.9 \%$ and $100 \%$ lower than controls, respectively (Table 2). In addition, all phosphite formulations evaluated significantly $(P<0.05)$ reduced leaf and fruit scab severity at the cessation of the growing season and increased leaf chlorophyll content. Within the phosphites tested the greatest reductions in leaf and fruit scab severity were achieved in the order: copper phosphite $(77.8 \%$, $100.0 \%)>$ silicon phosphite (66.7\%, 92.0\%) $>$ zinc phosphite $(55.6 \%, 80.0 \%)>$ calcium phosphite $(44.5 \%, 60.0 \%)>$ potassium phosphite $(33.3 \%, 60.0 \%)>$ control, where values in parenthesis represent percent leaf and fruit scab severity reductions from control trees, respectively.

Table 2. Yield, leaf chlorophyll content (SPAD), and visual index results of leaf and fruit scab severity on apple (Malus cv. Golden Delicious).

\begin{tabular}{|c|c|c|c|c|}
\hline Treatment & $\begin{array}{l}\text { Leaf scab } \\
\text { severity }\end{array}$ & $\begin{array}{l}\text { Fruit scab } \\
\text { severity }\end{array}$ & $\begin{array}{l}\text { Fruit yield/tree } \\
(\mathrm{kg})\end{array}$ & SPAD \\
\hline Control & 4.5 & 2.5 & 4.9 & 22.3 \\
\hline Penconazole & $0.5^{*}$ & $0.0^{*}$ & $7.5^{*}$ & $42.1^{\star}$ \\
\hline Potassium phosphite & $3.0^{*}$ & $1.0^{*}$ & $6.2^{\star}$ & $30.2^{*}$ \\
\hline Calcium phosphite & $2.5^{\star}$ & $1.0^{*}$ & $5.4 \mathrm{~ns}$ & $28.6^{*}$ \\
\hline Zinc phosphite & $2.0^{*}$ & $0.5^{\star}$ & $6.0^{*}$ & $33.9^{\star}$ \\
\hline Silicon phosphite & $1.5^{*}$ & $0.2^{*}$ & $6.4^{*}$ & $33.7^{\star}$ \\
\hline Copper phosphite & $1.0^{*}$ & $0.0^{*}$ & $7.1^{*}$ & $38.0^{*}$ \\
\hline
\end{tabular}

Note: Mean of eight randomized complete blocks with a single tree per block. Asterisk $\left.{ }^{*}\right)$ indicates significant difference from control $(P<0.05)$ based on least significant difference; $\mathrm{ns}=$ not significant from control value. 


\section{DISCUSSION}

Penconazole is a systemic fungicide with protective and curative action. It is classified as a sterol demethylation inhibitor that prevents cell membrane ergosterol biosynthesis of pathogenic fungi and thereby stops mycelial development and conidia formation (Kenyon et al. 1997). Penconazole, when sprayed onto plants, is absorbed by the leaves and translocated acropetally throughout the plant. The use of penconazole as a successful plant protection product has been widely documented. Work by Kenyon et al. (1997) showed penconazole as an extremely active compound that suppressed sporulation of powdery mildew in Rhododendron microplantlets compared to eight other fungicides recommended for mildew control. Schnabel and Parisi (1997) found a high level of control using penconazole against 44 strains of apple scab compared to several other synthetic fungicides. Likewise, Butt et al. (1990) found penconazole plus captan reduced powdery mildew infection of leaf tissue of orchard grown apple cv. Cox's Orange Pippin to a greater extent than several other fungicides tested. In support of these findings, penconazole treatment gave the greatest control of apple scab in this study, with increased fruit yield and improved leaf chlorophyll content. However, concerns regarding the future use of penconazole have been raised as recent studies indicate this fungicide is a potential mammalian endocrine disruptor and carcinogen, which may limit its commercial lifespan (Perdichizzi et al. 2014).

Copper phosphite gave the maximum reduction in leaf and fruit scab severity and promoted the highest fruit yields per plant of all phosphite formulations evaluated. Such a result could have been anticipated as copper is a widely used active ingredient for plant protection purposes. Copper oxychloride, copper (II) sulphate, copper hydroxide, and copper (I) oxide have all been shown to control a wide range of pathogenic fungi and bacteria (Johnson 1935; Jaros-Su et al. 1999; Gent and Schwartz 2005; Borkow and Gabbay 2009). Copper ions are absorbed into the cells of fungi and bacteria and are indiscriminately linked to several chemical groups present in cellular proteins (imidazoles, phosphates, sulfhydryls, hydroxyls), as well as specific enzymes, disrupting their function, ultimately resulting in cell death (U.S. Environmental Protection Agency 2009). Results indicate that copper phosphite would be an effective scab control in organic fruit production systems where copper-based plant protection products in the UK are permitted for use (Soil Association 2011). While organic consumers will tolerate small amounts of cosmetic scab imperfections on fruit (Bevan and Knight 2001), complete control of fruit scab may also make copper phosphite a viable scab control for 'zero tolerance' commercial markets (Butt et al. 1990).

Silicon sprays have shown only slight plant protectant activity against fruit scab in previous studies (Jamar et al. 2008). However, results of this study show silicon phosphite reduced leaf and fruit scab severity by $68 \%$ and $92 \%$, respectively, indicating silicon phosphite offers potential for apple scab control. Differences between the degrees of control in this study compared to that of Jamar et al. (2008) suggest a synergistic effect of silicon with the phosphite anion formulation used. Importantly silicon phosphite offers a comparatively high control of scab that does not contain a heavy metal cation, such as copper or zinc. This in turn potentially avoids contentious issues, including human exposure to heavy metals (Thompson et al. 2012) and impacts of phytotoxic heavy metal accumulation in plants and soils (Teviotdale and Viveros 1999; Aikpokpodion et al. 2010; Kurnik et al. 2010). Silicon is ubiquitous and has no recorded phytotoxicity (Epstein 1999); indeed silicon fertilization can mitigate the impact of excesses of heavy metals and other nutrients (Epstein 1999; Liang et al. 2005; Gu et al. 2011). Amorphous silicon dioxide forms the active ingredient of a range of physical insecticides successfully used for insect control (Percival et al. 2012). Diatomaceous earth is a powder mostly consisting of abrasive silicon dioxide particles, formed of the fossilized remains of diatoms and microscopic algae. When sprayed onto leaf tissue these particles adhere to the insect pest with particle damage to the cuticle through hydrocarbon absorption and physical abrasion, making the cuticle permeable to water and ultimately resulting in death from dehydration and desiccation (Korunic 1998; Doggett et al. 2008). Consequently, silicon phosphite, when applied as a foliar spray, offers a unique potential as a plant protection agent combating both pest and disease issues.

Evidence exists that enhancing calcium concentrations in leaf, stem, and root tissue by the use of calcium fertilizers can aid in the reduction of patho- 
gen severity caused by several fungi and bacteria (Percival et al. 2009). Pertinent examples include enhanced resistance against soft rot of potato caused by Erwinia carotovora subsp. amylovora (Bain et al. 1996), Phoma exigua (gangrene), and Fusarium solani (dry rot) (Olsson 1998), Botrytis cinerea of apple (Conway et al. 1991) and sweet cherries (Ippolito et al. 2005), and brown rot of peach caused by Monilinia fructicola (Elmer et al. 2006). Calcium is also known to directly affect some fruit pathogens by interfering with spore germination, germ tube elongation, and fungal cell wall thickness (Miceli et al. 1999; Chardonnet et al. 2000). The synthesis of plant protectant phytoalexin and phenolics substances has been reported to increase as a result of calcium application (Miceli et al. 1999; Glenn et al. 2001). Importantly, calcium phosphite provided a greater degree of scab control compared to the currently used potassium phosphite, although fruit yields were lower. Application of potassium phosphite and calcium phosphite together may improve the level of scab control and fruit yield. Calcium sprays provide other benefits to the fruit industry, such as enhanced fruit firmness and delayed ripening (Marschner 2012), as well as influencing other important commercial factors, such as aroma (Ortiz et al. 2011).

Zinc is a component of a number of carbamate (zineb, metiram, propineb) and thiadiazole fungicides used for plant pathogen control of agricultural crops-including wheat, barley, and potato-while zinc pyrithione is a widely used active ingredient in antifungal shampoos and soaps for human medical purposes (Reeder et al. 2011). Zinc oxide nanoparticles, zinc sulphate, and zinc perchlorate have also been shown to demonstrate antifungal properties (He et al. 2011; Savi et al. 2013). However these fungicides display differing modes of action on plant pathogens with in general the anion (carmomate, triazole) being of greater effect than the zinc cation. The zinc cation may, however, contribute indirectly to disease resistance via increased plant nutrition (Marschner 2012) and fruit quality (Zhang etal.2013).

\section{CONCLUSIONS}

Results of this study show that a range of commercially available phosphite formulations exist and provide higher degrees of control against the pathogen apple scab compared to potassium phosphite. Further evaluation against other pathogenic fungi and bacteria is warranted as, at least in the UK, phosphite formulations are classified as fertilizers or natural plant protection products and are not subject to the stringent government regulations regarding their registration and use compared to conventional synthetic fungicides. In urban environments where apple trees are planted for aesthetic purposes rather than for fruit production, phosphites may compliment conventional fungicide treatments, reduce their usage, or completely replace them where small amounts of scab are acceptable (Percival and Noviss 2010). Currently, the most widely used (potassium phosphite) performed poorly against the criteria assessed in this study, and is often the worst performing phosphite in terms of scab control. Replacement of potassium phosphite with differing phosphite formulations may be warranted for scab plant protection purposes.

Acknowledgments. The authors thank Miss Emma Schaffert for her help in conducting this experiment.

\section{LITERATURE CITED}

Aikpokpodion, P.E., L. Lajide, and A.F. Aiyesanmi. 2010. Heavy metals contamination in fungicide treated cocoa plantations in Cross River State, Nigeria. American-Eurasian Journal of Agricultural and Environmental Sciences 8(3):268-274.

Bain, R.A., and P. Millard, and M.C.M. Perombelon. 1996. The resistance of potato plants to Erwinia carotovora subsp. atroseptica in relation to their calcium and magnesium content. Potato Research 39(1):185-193.

Bevan, J., and S. Knight. 2001. Organic Apple Production: Pest and Disease Management. Emmerson Press, Kenilworth, UK. 36 pp.

Borkow, G., and J. Gabbay. 2009. Copper, an ancient remedy returning to fight microbial, fungal, and viral infections. Current Chemical Biology 3(3):272-278.

Butt, D.J., A.A.J Swait, and J.D. Robinson. 1990. Evaluation of fungicides against apple powdery mildew and scab. Tests of agrochemicals and cultivars 11. Annals of Applied Biology Supplement 116:34-35.

Chardonnet, C.O., C.E. Sams, R.N. Trigiano, and W.S. Conway. 2000. Variability of three isolates of Botrytis cinerea affects the inhibitory effects of calcium on this fungus. Phytopathology 90:769-774.

Conway, W.S., C.E. Sams, J.A. Abbott, and B.D. Bruton. 1991. Postharvest calcium treatment of apple fruit to provide broadspectrum protection against postharvest pathogens. Plant Disease 75:620-622.

Currie, H.A, and C.C. Perry. 2007. Silica in plants: Biological, biochemical, and chemical studies. Annals of Botany 100(7):13831389.

Doggett, S. L., M. J. Geary, D. Lilly, and R.C. Russell. 2008. The efficacy of diatomaceous earth against the common bed bug, Cimex lectularius. A report for Mount Sylvia Diatomite. 
Elmer, P.A.G., T.M. Spiers, and P.N. Wood. 2006. Effects of preharvest foliar calcium sprays on fruit calcium levels and brown rot of peaches. Crop Protection 26(1):11-18.

Epstein, E. 1999. Silicon. Annual Review of Plant Physiology and Plant Molecular Biology 50:641-664.

Epstein, E. 2001. Chapter 1 Silicon in plants: Facts vs. concepts. Studies in Plant Science 8:1-15.

Fauteux, F., F. Chain, F. Belzile, J.G. Menzies, and R.R. Bélanger. 2006. The protective role of silicon in the Arabidopsis-powdery mildew pathosystem. Proceedings of the National Academy of Sciences of the United States of America 103(46):17554-17559.

Fobert, P.R., and C. Després. 2005. Redox control of systemic acquired resistance. Current Opinion in Plant Biology 8:378-382.

Garbelotto, M., D.J. Schmidt, and T.Y. Harnik. 2007. Phosphite injections and bark application of phosphite + pentrabark $^{\mathrm{nt}}$ control sudden oak death. Arboriculture \& Urban Forestry 33:309-316.

Gent, D.H., and H.F. Schwartz. 2005. Management of Xanthomonas leaf blight of onion with a plant activator, biological control agents, and copper bactericides. Plant Disease 89(6):631-639.

Glenn, D.M., G.J. Puterka, S.R. Drake, T.R. Unruh, A.L. Knight, P. Baherle, E. Prado, and T. Baugher. 2001. Particle film application influences apple leaf physiology, fruit yield, and fruit quality. Journal of the American Society of Horticultural Science 126:175-181.

Gozzo, F. 2003. Systemic acquired resistance in crop protection: From nature to a chemical approach. Journal of Agriculture and Food Chemistry 51(16):4487-4503.

Gu, H-H., H. Qiu, T. Tian, S-S. Zhan, T-H-B. Deng, R.L. Chaney, S-Z. Wang, Y-T. Tang, J-L. Morel, and R-L. Qiu. 2011. Mitigation effects of silicon rich amendments on heavy metal accumulation in rice (Oryza sativa L.) planted on multi-metal contaminated acidic soil. Chemosphere 83(9):1234-1240.

Guest, D., and B. Grant. 1991. The complex action of phosphonates as antifungal agents. Biological Reviews 66:159-187.

He, L., Y. Liu, A. Mustapha, and M. Lin. 2011. Antifungal activity of zinc oxide nanoparticles against Botrytis cinerea and Penicillium expansum. Microbiological Research 166(3):207-215.

Ilhan, K., U. Arslan, and O.A. Karabulut. 2006. The effect of sodium bicarbonate alone or in combination with a reduced dose of tebuconazole on the control of apple scab. Crop Protection 25:963-967.

Ippolito, A., L. Schena, I. Pentimone, and F. Nigro. 2005. Control of postharvest rots of sweet cherries by pre-and postharvest applications of Aureobasidium pullulans in combination with calcium chloride or sodium bicarbonate, Postharvest Biology and Technology 36:245-252.

Jackson, T.J., T. Burgess, I. Colquhoun, G.E. St J. Hardy. 2000. Action of the fungicide phosphite on Eucalyptus marginata inoculated with Phytophthora cinnamomi. Plant Pathology 49:147-154.

Jamar, L., B. Lefrancq, C. Fassotte, and M. Lateur. 2008. A duringinfection spray strategy using sulphur compounds, copper, silicon, and a new formulation of potassium bicarbonate for primary scab control in organic apple production. European Journal of Plant Pathology 122(4):481-493.

Jaros-Su, J., E. Groden, and J. Zhang. 1999. Effects of selected fungicides and the timing of fungicide application on Beauveria bassiana-induced mortality of the Colorado potato beetle (Coleoptera: Chrysomelidae). Biological Control 15(3):259-26.

Johnson, G.F. 1935. The early history of copper fungicides. Agricultural History 9(2):67-79.
Kenyon, D.M., G.R. Dixon, and S. Helfer. 1997. The repression and stimulation of growth of Erysiphe sp. on Rhododendron by fungicidal compounds. Plant Pathology 46:425-431.

Korunic, Z. 1998. Diatomaceous earths, a group of natural insecticides. Journal of Stored Products Research 34:87-97.

Kurnik, V., V. Gaberšek, and M. Lešnik. 2010. Influence of copper fungicide/fertilizer formulations applied during the blooming period on a fruit set of apples. Agricultura 7:23-30.

Liang, Y., J.W. Wong, and L. Wei. 2005. Silicon-mediated enhancement of cadmium tolerance in maize (Zea mays L.) grown in cadmium contaminated soil. Chemosphere 58(4):475-83.

Lichtenthaler, H.K., and A.R. Wellburn. 1983. Determinations of total carotenoids and chlorophylls $\mathrm{a}$ and $\mathrm{b}$ of leaf extracts in different solvents. Biochemical Society Transactions 11:591-593.

Lobato, M.C., F.P. Olivieri, E.A. González Altamiranda, E.A. Wolski, G.R. Daleo, D.O. Caldiz, and A.B. Andreu. 2008. Phosphite compounds reduce disease severity in potato seed tubers and foliage. European Journal of Plant Pathology 122:349-358.

Marschner, P. (Ed.). 2012. Marschner's Mineral Nutrition of Higher Plants. Third Edition. Academic Press, London, England.

Miceli, A., A. Ippolito, V. Linsalata, and F. Nigro. 1999. Effect of preharvest calcium treatments on decay and biochemical changes in table grape during storage. Phytopathology Mediterranea 38:47-53.

Miller, J.S., N. Olson, L. Woodell, L.D. Porter, and S. Clayson. 2006. Post-harvest applications of zoxamide and phosphite for control of potato tuber rots caused by oomycetes at harvest. American Journal of Potato Research 83(3):269-278.

Nägeli, K.W. 1893. Über oligodynamische Erscheinungen in lebenden Zellen. Neue Denk-schriften der schweizerischen naturforschenden Gesellschaft 33-34:1-5.

Olsson,K.1988. Resistancetogangrene(Phomaexiguavar.foveata) and dry $\operatorname{rot}($ Fusarium solani var. coeruleum) in potato tubers. 1. The influence of pectin-bound magnesium and calcium. Potato Research 31:413-422.

Ortiz, A., J. Graell, and I. Lara. 2011. Preharvest calcium sprays improve volatile emission at commercial harvest of 'Fuji Kiku-8' apples. Journal of Agricultural and Food Chemistry 59(1):335-341.

Percival G.C., J. Banks, and I. Keary. 2012. Evaluation of organic, synthetic, and physical insecticides for the control of horse chestnut leaf miner (Cameraria ohridella). Urban Forests \& Urban Greening 11:426-431.

Percival, G.C., and K. Noviss. 2010. Potassium phosphite and myclobutanil for pear scab (Venturia pirina) suppression. Arboriculture \& Urban Forestry 36(2):86-92.

Percival, G.C., K. Noviss, and I. Haynes. 2009. Field evaluation of systemic inducing resistance chemicals at different growth stages for the control of apple (Venturia inaequalis) and pear (Venturia pirina) scab. Crop Protection 28(8):629-633.

Perdichizzi, S., M. Grazia Mascolo, P. Silingardi, E. Morandi, F. Rotondo, A. Guerrini, L. Prete, M. Vaccari, and A. Colacci. 2014. Cancer-related genes transcriptionally induced by the fungicide penconazole. Toxicology in Vitro 28(1):125-130.

Reeder, N.L., J. Xu, R.S. Youngquist, J.R. Schwartz, R.C. Rust, and C.W. Saunders. 2011. The antifungal mechanism of action of zinc pyrithione. British Journal of Dermatology 165:9-12.

Savi, G.D., A.J. Bortoluzzi, and V.M. Scussel. 2013. Antifungal properties of zinc-compounds against toxigenic fungi and mycotoxin. International Journal of Food Science \& Technology $48: 1834-1840$ 
Schnabel, G., and L. Parisi. 1997. Sensitivity of Venturia inaequalis to five DMI fungicides, including the new triazole fluquinconazole, and to pyrimethanil. Journal of Plant Disease Protection 104: 36-46.

Soil Association. 2011. Materials for pest and disease control in organic crops fact sheet. Accessed 01/22/2014. <www.soilassociation.org/LinkClick.aspx>

Swait, A.A.J., and D.J. Butt. 1990. Fungicides as antisporulants against apple powdery mildew and scab. Tests of Agrochemicals and Cultivars 11. Annals Applied Biology (supplement) 116:36-37.

Teviotdale, B.L., and M.Viveros. 1999. Fruit russeting and treetoxicity symptoms associated with copper treatments of Granny Smith apple trees (Malus Sylvestris Mill.). Acta Horticulturae (ISHS) 489:565-572.

Thompson, T., D. Freestone, A.A. Michalczyk, and M.L. Ackland. 2012. Copper levels in buccal cells of vineyard workers engaged in various activities. Annals of Occupational Hygiene 56(3):305-14.

U.S. Environmental Protection Agency. 2009. Reregistration Eligibility Decision (RED) for Coppers; U.S. Environmental Protection Agency, Office of Prevention, Pesticides and Toxic Substances, Office of Pesticide Programs, U.S. Government Printing Office: Washington, D.C., U.S.

Zhang, Y., C. Fu, Y. Yan, Y. Wang, M. Li, M. Chen, J. Qian, X. Yang, and S. Cheng. 2013. Zinc sulfate and sugar alcohol zinc sprays at critical stages to improve apple fruit quality. HortTechnology 23:490-497.

Luke E. Hailey

Bartlett Tree Experts Research Laboratory

Cutbush Lane, Shinfield

Reading, Berkshire RG2 9AF

lhailey@bartlettuk.com

Glynn C. Percival (corresponding author)

Bartlett Tree Experts Research Laboratory

Cutbush Lane, Shinfield

Reading, Berkshire RG2 9AF

gpercival@bartlettuk.com
Zusammenfassung. Kaliphosphat wird häufig im Pflanzenschutz genutzt. Dennoch sind auch verschiedene PhosphatVerbindung mit alternativen Kationen-Verbindungen (Kalzium, Kupfer, Silikon, Zink) käuflich erhältlich. Die Pflanzenschutzeigenschaften dieser Verbindungen haben wenig Aufmerksamkeit erhalten. Diese Studie bewertet fünf Phosphat-Verbindungen für den Pflanzenschutz im Einsatz gegen den Blattschädling Apfelschorf (Venturia inaequalis) unter Feldbedingungen. Zusätzlich wurde eine vergleichende Analyse gegen das synthetische Fungizid Penconazol, welches weit verbreitet gegen Apfelschorf eingesetzt wird, durchgeführt. Durch ein Besprühung mit dem synthetischen Fungizid Penconazol wurde die größte Reduktion bei Blatt- und Fruchtschorfbefall erzielt. Trotzdem haben alle bewerteten Phosphatverbindungen den Frucht- und Blattschorfbefall am Ende der Vegetationsperiode signifikant reduziert. Unter den getesteten Phosphaten konnte die größte Reduktion des Frucht- und Blattschorfbefalls in der Reihenfolge: Kupferphosphat, Silikonphosphat, Zinkphosphat, Kalziumphosphat, Kaliumphosphat erzielt werden. Die Vor- und Nachteile dieser Phosphat-Verbindungen bei der Schorfkontrolle werden hier diskutiert.

Resumen. El fosfito de potasio es un agente de protección vegetal ampliamente utilizado. Sin embargo, un conjunto de formulaciones de fosfito con cationes agregados (calcio, cobre, silicio, zinc) están disponibles comercialmente. Las propiedades protectoras a las plantas por estas formulaciones han recibido poca atención. Este estudio evaluó cinco formulaciones de fosfito con fines fitosanitarios contra el patógeno foliar roya de la manzana (Venturia inaequalis) en condiciones de campo. Además, se llevó a cabo un análisis comparativo con el penconazol, fungicida sintético ampliamente utilizado para el control de la roya del manzano. Reducciones más grandes de la severidad de roya en la hoja y la fruta se lograron mediante aerosoles del penconazol. Sin embargo, todas las formulaciones de fosfito evaluadas redujeron significativamente la costra en la hoja y la fruta al cese de la temporada de crecimiento. Dentro de los fosfitos probados, las mayores reducciones de la costra de la hoja y la fruta se lograron en el orden: fosfito de cobre $>$ fosfito de silicio $>$ fosfito de zinc $>$ fosfito de calcio $>$ fosfito de potasio $>$ control. Se discuten las ventajas y desventajas de estas formulaciones de fosfito para el control de la roya. 